\title{
KARAKTERISASI SIMPLISIA, EKSTRAK, DAN FRAKSI DAUN SUKUN (ARTOCARPUS ALTILIS) SERTA BIOAKTIVITAS TERHADAP ARTEMIA SALINA LEACH
}

\author{
Iswahyudi, Jaka Fadraersada, Muhammad Amir Masruhim \\ Laboratorium Penelitian dan Pengembangan FARMAKA TROPIS, Fakultas Farmasi, \\ Universitas Mulawarman, Samarinda, Kalimantan Timur \\ E-mail: iswahyudifarm@gmail.com
}

\begin{abstract}
ABSTRAK
Telah dilakukan penelitian dengan judul Karakterisasi Simplisia, Ekstrak, dan Fraksi Daun Sukun (Artocarpus altilis) Serta Bioaktivitas Terhadap Artemia salina Leach. Penelitian ini bertujuan untuk menentukan parameter mutu simplisia dan ekstrak daun sukun serta bioaktivitas ekstrak dan fraksi daun sukun terhadap larva Artemia salina Leach dengan metode BSLT (Brine Shrimp Lethality Test). Data yang diperoleh dianalisis menggunakan metode Reed and Muench untuk mendapatkan nilai Lethality Concentration 50\% ( $\left.\mathrm{LC}_{50}\right)$. Hasil organoleptis menunjukkan bahwa daun sukun bertulang daun menyirip, lebar dan berbulu kasar di permukaan atas dan bawah daun. Pengamatan mikroskopik daun menunjukkan bentuk stomata daun sukun merupakan tipe anomositik. Tipe ini memiliki tiga atau lebih sel tetangga dan sulit untuk dibedakan. Persentase susut pengeringan yang diperoleh dari simplisia daun sukun sebesar $11,2 \%$, kadar larut air dan kadar larut etanol sebesar 2,03\% dan 1,4\% serta kadar abu total, kadar abu larut air, dan kadar abu tidak larut asam daun sukun sebesar 10,3\%, 1,7\%, dan 9,1\%. Persentase kadar larut air dan etanol pada ekstrak daun sukun sebesar 17,1\% dan 6,9\%, kadar abu total, kadar abu larut air, dan kadar abu tidak larut asam ekstrak daun sukun sebesar 3,3\%, 1,2\%, dan 0,7\%. Daun sukun memiliki nilai $\mathrm{LC}_{50}$ dari masing-masing ekstrak kasar, fraksi $n$-heksan, fraksi etil asetat, dan fraksi $n$-butanol sebesar 434,9 ppm, 537,03 ppm, 448,2 ppm, dan 670,5 ppm. Hasil ini menunjukkan bahwa esktrak maupun fraksi daun sukun berpotensi sebagai pestisida.
\end{abstract}

Kata kunci: $\quad$ Artemia salina Leach, Artocarpus altilis, Lethality Concentration 50\%

\begin{abstract}
A research with the title of Characterization of Simplisia, Extracts, and Fractions of Breadfruit Leaves (Artocarpus altilis) and Bioactivity Againts Artemia salina Leach. This research aims to determine the quality parameters of simplisia and extracts of breadfruit leaves and bioactivity of extracts and fractions of breadfruit leaves againts Artemia salina Leach using Brine Shrimp Lethality Test (BSLT). Data were obtained and analyzed using the method of Reed and Muench to get the Lethality Concentration $50 \%\left(L C_{50}\right)$. The result of organoleptic showed that breadfruit leaves has pinnately lobed, width, and brushy at the upper and lower surfaces of leaves. Microscopic observation of breadfruit leaves showed that the shape of the stomata is anomocytic. In this type, there are three or more subsidiary cells and they are difficult to distinguish. Drying shrinkage percentage obtained from simplisia of breadfruit leaves is 11,2\%, water soluble content and ethanol soluble content is $2,03 \%$ and $1,4 \%$, and ash content, water soluble ash content, and acid insoluble ash content is $10,3 \%, 1,7 \%$, and 9,1\%. Water soluble content and ethanol soluble content
\end{abstract}


percentage of extracts of breadfruit leaves is $17,1 \%$ and $6,9 \%$, ash content, water soluble ash content, and acid insoluble ash content of extracts of breadfruit leaves is 3,3\%, 1,2\%, and $0,7 \%$. Breadfruit leaves has an $L C_{50}$ of each extract, fraction of $n$-hexane, fraction of ethyl acetate, and fraction of n-butanol is 434,9 ppm, 537,03 ppm, 448,2 ppm, and 670,5 ppm. The results showed that extracts and fractions of breadfruit leaves have potential as pesticide.

Keyword: $\quad$ Artemia salina Leach, Artocarpus altilis, Lethality Concentration 50\%

\section{PENDAHULUAN}

Indonesia merupakan salah satu negara dengan iklim tropis yang memiliki kekayaan melimpah akan sumber daya alam. Keadaan iklim ini juga yang menyebabkan Indonesia menjadi habitat yang baik untuk tumbuh-tumbuhan atau tanaman yang beraneka ragam. Kekayaan Indonesia akan sumber daya alam terutama tumbuh-tumbuhan yang memiliki potensi dan mulai diekploitasi keberadaan dan kemanfaatannya dikalangan masyarakat, baik sebagai bahan pangan, papan, atau sebagai bahan obat yang merupakan yang paling umum dilakukan saat ini karena masyarakat Indonesia yang secara empiris menggunakan tumbuhan sebagai bahan pengobatan tradisional dalam penanganan penyakit.

Salah satu tanaman yang dapat dijadikan sebagai kandidat bahan obat adalah sukun, khususnya pada bagian daun. Hal ini dikarenakan tanaman sukun merupakan tanaman yang terlihat dapat tumbuh bebas di sekitar pekarangan rumah, namun masih jarang dimanfaatkan untuk pengobatan. Untuk pemanfaatan tanaman menjadi bahan pengobatan, perlu dilakukan skrining awal untuk mengetahui toksisitas dari senyawa yang terkandung dalam tanaman dengan menggunakan uji bioaktivitas. Brine Shrimp Lethality Test (BSLT) merupakan salah satu metode yang dapat digunakan karena cepat, mudah, dan sederhana. Parameter yang digunakan untuk menunjukkan aktivitas biologi dari senyawa yang terkandung dalam tanaman adalah jumlah kematian dari bioindikator uji, yaitu larva Artemia salina Leach yang kemudian akan ditentukan tingkat ketoksikan senyawa yang dinyatakan dalam nilai $\mathrm{LC}_{50}$ (Lethality Concentration 50\%). Nilai $\mathrm{LC}_{50}$ merupakan angka yang menunjukkan konsentrasi ekstrak suatu tanaman yang dapat menyebabkan kematian hewan uji sebesar 50\% dari jumlah hewan uji. Hasil uji dinyatakan toksik apabila nilai $\mathrm{LC}_{50} \leq 1000 \mu \mathrm{g} / \mathrm{mL}$.

Sebelum suatu tanaman dijadikan sebagai bahan obat, perlu dilakukan pengendalian mutu simplisia. Salah satu cara pengendalian mutu simplisia adalah dengan melakukan standarisasi simplisia atau karakterisasi simplisia. Persyaratan tertentu yang digunakan dalam karakterisasi simplisia meliputi organoleptis simplisia, susut pengeringan, kadar air, kadar abu total, kadar abu tidak larut asam, kadar sari larut air, dan kadar sari larut etanol.

Berdasarkan hal tersebut, maka perlu dilakukan penelitian karakterisasi simplisia dan ekstrak daun sukun, serta bioaktivitas ekstrak dan fraksi daun sukun untuk mengetahui mutu simplisia dan tingkat ketoksikannya jika digunakan sebagai bahan baku obat dan data karakterisasi yang diperoleh dapat digunakan sebagai standar pengadaan bahan baku tanaman yang akan digunakan.

\section{METODE PENELITIAN}

\section{Bahan}

Bahan yang telah diteliti adalah tanaman sukun (Artocarpus altilis). Bagian yang diteliti adalah daun yang masih segar dan berwarna hijau tua. Daerah pengambilan sampel ini terletak di daerah Samarinda, Kalimantan Timur. 


\section{Peralatan}

Peralatan yang digunakan dalam penelitian ini antara lain, bejana maserasi, rotary evaporator (büchi rotavapor R-200), waterbath (Memmert ${ }^{\circledR}$ ), timbangan analitik (Precisa), cawan porselin, labu ukur $\left(\right.$ Pyrex $\left.^{\circledR}\right)$, stirer, mikro pipet (Socorex), erlenmeyer (Pyrex $\left.{ }^{\circledR}\right)$, oven (Froilabo), tanur (Stuart), mikroskop (Carton), dan alat penunjang lainnya.

\section{Prosedur penelitian}

\section{Prosedur Pengumpulan dan Penyiapan Sampel}

Daun sukun diperoleh dari daerah Samarinda, Kalimantan Timur. Daun sukun segar dikumpulkan kemudian disortasi basah. Setelah itu, dicuci dan dikeringkan dengan cara diangin-anginkan di dalam ruangan yang terlindung dari sinar matahari. Selanjutnya daun sukun kering dipotong kecil-kecil menjadi serbuk simplisia.

\section{Prosedur Ekstraksi}

Serbuk simplisia dimasukkan kedalam bejana maserasi dan dimaserasi menggunakan pelarut metanol. Proses ekstraksi dengan metode maserasi berlangsung selama kurang lebih 5 hari. Maserat (hasil maserasi) disaring menggunakan kertas saring dan ditampung kedalam wadah. Maserat kemudian dipekatkan menggunakan rotary evaporator dan dilanjutkan dengan penguapan menggunakan waterbath hingga diperoleh ekstrak metanol kental, setelah itu disimpan dalam desikator.

\section{Prosedur Pengujian organoleptik}

Sampel diraba dan diamati dengan indera peraba dan penglihatan. Setelah itu diamati bentuk dan diraba permukaan sampel daun sukun.

\section{Prosedur Pengujian Mikroskopik}

Serbuk simplisia diletakkan di atas kaca objek dan ditetesi pelarut tertentu. Kemudian ditutup dengan kaca penutup. Setelah itu, diamati dengan mikroskop.

\section{Prosedur Pengujian Susut Pengeringan}

Simplisia ditimbang menggunakan cawan porselin yang telah diketahui berat kosongnya. Kemudian dikeringkan pada suhu $105^{\circ} \mathrm{C}$ dan ditimbang hingga bobot tetap.

\section{Prosedur Pengujian Kadar Zat Larut Air}

Simplisia maupun ekstrak ditambahkan $100 \mathrm{~mL}$ campuran air : kloroform (1:1) di dalam Erlenmeyer bertutup. Kemudian dikocok dan didiamkan selama 24 jam. Setelah itu, disaring dan filtrat yang diperoleh diuapkan hingga kering kemudian dipanaskan pada suhu $105^{\circ} \mathrm{C}$ hingga diperoleh bobot tetap.

\section{Prosedur Pengujian Kadar Zat Larut Etanol}

Simplisia maupun ekstrak ditambahkan $100 \mathrm{~mL}$ etanol di dalam Erlenmeyer bertutup. Kemudian dikocok dan didiamkan selama 24 jam. Setelah itu, disaring dan filtrate yang diperoleh diuapkan hingga kering kemudian dipanaskan pada suhu $105^{\circ} \mathrm{C}$ hingga diperoleh bobot tetap.

\section{Prosedur Pengujian Kadar Abu Total}

Simplisia maupun ekstrak diletakkan di dalam cawan krus lalu dipijar di dalam tanur pada suhu $600^{\circ} \mathrm{C}$ selama 3 jam sampai menjadi abu kemudian didinginkan. Abu yang diperoleh kemudian dtimbang dan didapatkan berat abu. 


\section{Prosedur Pengujian Kadar Abu Larut Air}

Hasil dari abu total kemudian ditambahkan air sebanyak $25 \mathrm{~mL}$ kemudian dididhkan selama 15 menit. Abu yang tidak larut kemudian dicuci dengan air panas lalu dipijar dan hasilnya kemudian ditimbang hingga bobot tetap.

\section{Prosedur Pengujian Kadar Abu Tidak Larut Asam}

Hasil dari abu total kemudian ditambahkan asam klorida $3 \mathrm{~N}$ sebanyak $25 \mathrm{~mL}$ kemudian dididihkan selama 15 menit. Abu yang tidak larut kemudian dicuci air panas dan dipijar. Hasil yang diperoleh kemudian ditimbang hinnga bobot tetap.

\section{Prosedur Pengujian Bioaktivitas}

\section{Penyiapan Bioindikator Uji}

Telur Artemia salina dimasukkan ke dalam wadah yang berisi air laut kemudian dibiarkan pada suhu kamar dengan bantuan cahaya lampu dan aerator serta diberikan pakan ragi. Setelah larva berumur 48 jam, maka siap untuk diuji.

\section{Pembuatan Larutan Stok}

Ditimbang ekstrak maupun fraksi sebanyak 0,1 gram kemudian dilarutkan dengan air laut sebanyak $100 \mathrm{~mL}$ (larutan stok $1000 \mathrm{ppm}$ ).

\section{Pembuatan Seri Konsentrasi}

Diambil masing-masing $0,5 \mathrm{~mL}, 1,5 \mathrm{~mL}, 2,5 \mathrm{~mL}, 3,5 \mathrm{~mL}$, dan 4,5 mL dari larutan stok ekstrak maupun fraksi untuk membuat konsentrasi 100 ppm, 300 ppm, 500 ppm, 700 ppm, dan 900 ppm.

\section{Pengujian Bioaktivitas}

Masing-masing 10 ekor larva dimasukkan ke dalam 6 botol vial (5 vial sebagai uji dan 1 vial sebagai uji) kemudian ditambahkan ekstrak atau fraksi yang telah ditentukan jumlahnya ke tiap vial sesuai seri konsentrasinya. Selanjutnya ditambahkan ragi (konsentrasi $3 \mathrm{mg} / 5 \mathrm{~mL}$ ) sebanyak 1 tetes ke tiap vial. Lalu diinkubasi dibawah cahaya lampu pada suhu kamar selama 24 jam. Setelah 24 jam, diamati jumlah larva yang mati dan dihitung nilai $\mathrm{LC}_{50}$ menggunakan metode analisa Reed and Muench.

\section{HASIL DAN PEMBAHASAN}

\section{Pengujian Organoleptik}

Bentuk daun melebar, ujung runcing, dan memiliki bulu kasar di bagian permukaan atas maupun bawah daun. Tulang daun menyirip, tebal, dan berwarna kuning kehijauan.

\section{Pengujian Mikroskopik}

Pengamatan mikroskopik dilakukan untuk mengetahui bentuk stomata dan bagian lain dari sel daun sukun. Pelarut yang digunakan adalah perbandingan 3:1 etanol 96\% dengan $\mathrm{HCl} 37 \%$ 


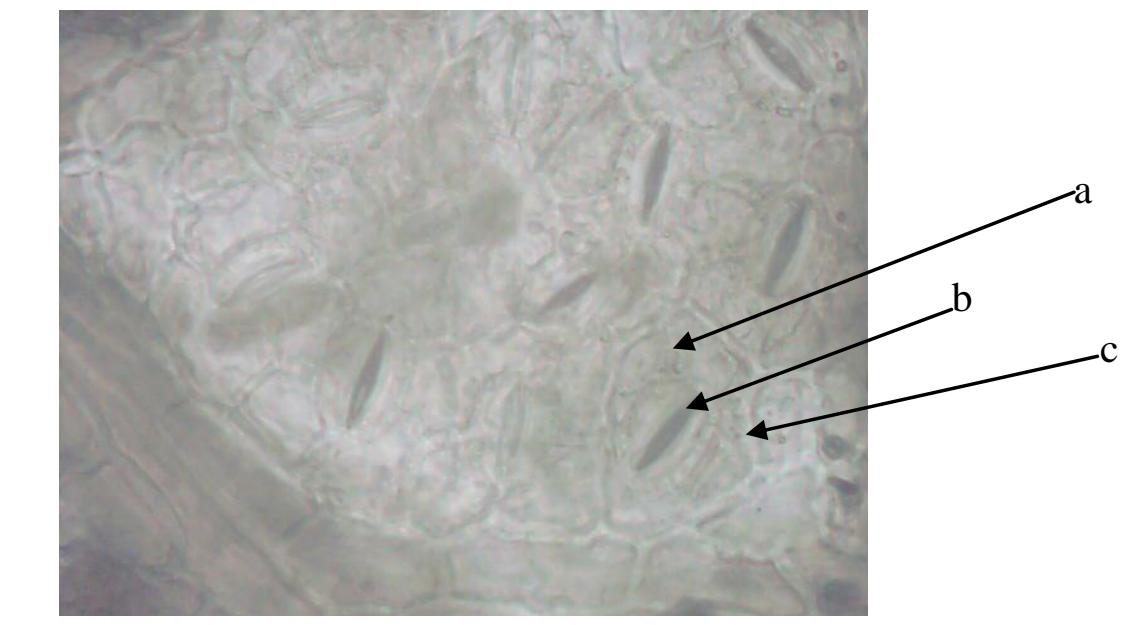

Gambar 1. Pengamatan Mikroskop Sel Daun Sukun

Berdasarkan gambar di atas, dapat terlihat bentuk stomata dari sel daun sukun termasuk tipe anomositik yaitu jumlah sel tetangga tiga atau lebih, satu sama lain sukar dibedakan. Bagian a adalah sitoplasma yang fungsinya sebagai tempat penyimpanan bahan-bahan kimia yang penting bagi metabolisme sel. Bagian $b$ adalah lubang stomata yang menjadi tempat terjadinya transpirasi tanaman. Bagian $\mathrm{c}$ adalah dinding sel yang menjadi pelindung dari isi sel tanaman.

\section{Pengujian Susut Pengeringan}

Susut pengeringan merupakan parameter untuk mengetahui penyusutan maksimal suatu bahan saat dikeringkan. Digunakan suhu $105^{\circ} \mathrm{C}$ agar kandungan air di dalam simplisia dapat menguap. Jumlah penyusutan dari sampel kering daun sukun adalah 11,2\%.

\section{Pengujian Kadar Zat Larut Air dan Etanol}

Jumlah zat yang terlarut dalam suatu pelarut tertentu menunjukkan bahan tersebut dominan terlarut ke dalam suatu pelarut. Semakin banyak zat yang terlarut dalam suatu pelarut, maka semakin dominan bahan tersebut terlarut dalam pelarut tersebut. Hal ini bertujuan untuk memudahkan dalam penanganan bahan saat akan digunakan dalam bentuk terlarutnya. Hasil pengujian kadar zat larut air dan etanol:

Tabel 1. Kadar Zat Larut dalam Pelarut Air dan Etanol Simplisia Daun Sukun Parameter Zat Terlarut Kadar Terlarut (\%)

Zat larut air 1,4

Zat larut etanol $\quad 2,03$

Tabel 2. Kadar Zat Larut dalam Pelarut Air dan Etanol Ekstrak Daun Sukun

\begin{tabular}{cc}
\hline Parameter Zat Terlarut & Kadar Terlarut (\%) \\
\hline Zat larut air & 6,9 \\
Zat larut etanol & 17,1 \\
\hline
\end{tabular}


Berdasarkan hasil pengujian kadar zat larut air dan etanol baik simplisia maupun ekstrak daun sukun, menunjukkan bahwa kedua pengujian lebih dominan terlarut di dalam etanol dibandingkan di dalam air dengan masing-masing persentase yaitu $2,03 \%$ dan $17,1 \%$.

\section{Pengujian Kadar Abu Simplisia dan Ekstrak Daun Sukun}

Pengujian kadar abu digunakan untuk mengetahui jumlah unsur-unsur seperti logam yang tertarik oleh tumbuhan selama proses pertumbuhan suatu tumbuhan. Pada proses pengabuan, seluruh zat organik akan terbakar menjadi arang yang dalam pemanasan berlanjut akan habis terbakar kecuali zat anorganik yang akan menjadi abu yang merupakan sisa pembakaran. Hasil pengujian kadar abu larut air simplisia dan ekstrak daun sukun:

Tabel 3. Kadar Abu Total dan Abu Larut Air Simplisia dan Esktrak Daun Sukun

\begin{tabular}{ccc}
\hline \multirow{2}{*}{ Parameter Abu } & \multicolumn{3}{c}{ Kadar Abu (\%) } \\
\cline { 2 - 3 } & Simplisia & Ekstrak \\
\hline Abu total & 10,3 & 3,3 \\
Abu larut air & 1,7 & 1,5 \\
\hline
\end{tabular}

Berdasarkan hasil pengujian, dapat terlihat bahwa persentase kadar abu larut air pada ekstrak lebih banyak terlarut dalam air. Hasil ini menunjukkan bahwa bahan-bahan anorganik yang ada di ekstrak termasuk bahan-bahan yang mudah terlarut di dalam air.

Tabel 4. Kadar Abu Total dan Abu Tidak Larut Asam Simplisia dan Ekstrak Daun Sukun

\begin{tabular}{ccc}
\hline \multirow{2}{*}{ Parameter Abu } & \multicolumn{3}{c}{ Kadar Abu (\%) } \\
\cline { 2 - 3 } & Simplisia & Ekstrak \\
\hline Abu total & 10,3 & 3,3 \\
Abu tidak larut asam & 9,1 & 0,7 \\
\hline
\end{tabular}

Berdasarkan hasil pengujian, kadar abu tidak larut asam pada simplisia lebih besar daripada ekstrak. Hal ini menunjukkan bahwa bahan-bahan anorganik yang terdapat pada simplisia tidak dapat terdenaturasi oleh asam sehingga masih tetap tertinggal saat dilarutkan dengan asam. Hal berbeda terlihat pada kadar abu tidak larut asam pada ekstrak yang dominan bahan-bahan anorganiknya mudah terlarut oleh asam.

\section{Pengujian Bioaktivitas}

Parameter dalam pengujian bioaktivitas dengan metode Brine Shrimp Lethality Test adalah jumlah kematian larva Artemia salina Leach yang akan dihitung untuk penentuan nilai $\mathrm{LC}_{50}$. Ekstrak bersifat toksik bila harga $\mathrm{LC}_{50}$ nya $<1000$ ppm. Ekstrak atau fraksi senyawa yang memiliki nilai $\mathrm{LC}_{50}<30 \mathrm{ppm}$ berpotensi sebagai sitotoksik, $\mathrm{LC}_{50}$ 30-200 ppm berpotensi sebagai antibakteri, sedangkan $\mathrm{LC}_{50}$ 200-1000 ppm berpotensi sebagai pestisida (Restasari, 2009). Nilai $\mathrm{LC}_{50}$ ekstrak dan fraksi daun sukun: 
Tabel 5. Nilai LC $_{50}$ Ekstrak dan Fraksi Daun Sukun

\begin{tabular}{lll}
\hline No. & Sampel & $\mathrm{LC}_{50}(\mathrm{ppm})$ \\
\hline 1. & Ekstrak kasar & 434,9 \\
2. & Fraksi n-heksan & 537,03 \\
3. & Fraksi etil asetat & 448,2 \\
4. & Fraksi n-butanol & 670,5 \\
\hline
\end{tabular}

Berdasarkan hasil pengujian, nilai $\mathrm{LC}_{50}$ dari ekstrak maupun fraksi daun sukun masih masuk dalam rentang toksik karena kurang dari 1000 ppm dan berpotensi sebagai pestisida (rentang $\mathrm{LC}_{50}$ antara 200-1000 ppm).

\section{KESIMPULAN}

1. Organoleptis daun sukun memiliki daun yang lebar, ujung runcing,berbulu kasar di permukaan atas dan bawah daun serta bertulang daun tebal dan menyirip. Pengamatan mikroskopik menunjukkan bentuk stomata daun sukun termasuk tipe anomositik.

2. Persentase susut pengeringan simplisia daun sukun sebesar $11,2 \%$.

3. Kadar zat larut air dan etanol simplisia daun sukun sebesar 1,4\% dan 2,03\% serta kadar zat larut air dan etanol ekstrak daun sukun sebesar 6,9\% dan 17,1\%.

4. Kadar abu total, kadar abu larut air dan kadar abu tidak larut asam simplisia daun sukun sebesar 10,3\%, 1,7\%, dan 9,1\% serta kadar abu total, kadar abu larut air, dan kadar abu tidak larut asam ekstrak daun sukun sebesar 3,3\%, 1,5\%, dan 0,7\%.

5. Nilai $\mathrm{LC}_{50}$ ekstrak kasar, fraksi n-heksan, fraksi etil asetat, dan fraksi n-butanol daun sukun sebesar 434,9 ppm, 537,03 ppm, 448,2 ppm, dan 670,5 ppm. Esktrak dan berbagai fraksi daun sukun berpotensi sebagai pestisida.

\section{SARAN}

a. Perlu dilakukannya penelitian lebih lanjut dengan menggunakan metode penyarian atau metode ektraksi yang berbeda.

b. Perlu dilakukan penelitian lanjutan mengenai aktivitas daun sukun sebagai bahan baku obat.

\section{DAFTAR PUSTAKA}

1. Direktorat Jenderal Pengawasan Obat dan Makanan. 1995. Materia Medika Indonesia Edisi VI (enam). Departemen Kesehatan Republik Indonesia. Jakarta

2. Direktorat Jenderal Pengawasan Obat dan Makanan. 2000. Parameter Standar Umum Ekstrak Tumbuhan Obat. Departemen Kesehatan Republik Indonesia

3. Iskandar, Yopi, Lia Marliani, dan Jon Fiter Irawan. 2012. Toksisitas Ekstrak Etanol dan Fraksi-fraksi Daun Sirsak (Annona muricata L.) Menggunakan BSLT (Brine Shirmp Lethality Test). Laboratorium Fitokimia Sekolah Tinggi Farmasi Bandung. Bandung

4. Restasari, A., Kusrini, D., dan Fachriyah, E. 2009. Isolasi dan Identifikasi Fraksi Teraktif dari Ekstrak Kloroform Daun Ketapang (Terminalia catappa Linn.). Universitas Diponegoro. Semarang 